\title{
Distribution of extracellular signal-regulated protein kinases 1 and 2 in the rat adrenal and their activation by angiotensin II
}

\author{
H McNeill, E Whitworth, G P Vinson and J P Hinson ${ }^{1}$ \\ School of Biological Sciences, Queen Mary, University of London and 'William Harvey Research Institute, Barts and the London, Queen Mary's School of \\ Medicine and Dentistry, University of London, London, UK \\ (Requests for offprints should be addressed to J P Hinson, Centre for Endocrinology, William Harvey Research Institute, Barts and the London, Queen Mary's \\ School of Medicine and Dentistry, First Floor, John Vane Science Centre, Charterhouse Square, London EC1 M 6BQ, UK; Email: j.p.hinson@qmul.ac.uk)
}

\begin{abstract}
The adrenal gland of the rat is continuously regenerated through proliferation of a stem cell population in the outer part of the gland. To clarify the location of proliferative events within the adrenal gland, and the factors that stimulate them, rat adrenal capsule preparations, consisting of capsule, zona glomerulosa $(\mathrm{ZG})$ and the outer zona fasciculata $(\mathrm{ZF})$ were maintained in vitro under different conditions of stimulation, for varying periods. Sites of proliferation were identified by 5-bromo-2'-deoxyuridine (BrdU) staining, and the distribution of classical MAP kinase (MAPK) family members, extracellular signal-regulated kinase (ERK) 1 and 2, immunoreactivity was determined using immunocytochemistry. BrdU staining was limited to the outer glomerulosa and the capsule, where it was enhanced by angiotensin II, but not by a high potassium ion concentration nor by ACTH. In contrast,
\end{abstract}

ERK1/2 immunoreactivity was distributed throughout the $\mathrm{ZG}$ and in the medulla, with none detectable in the $\mathrm{ZF}$ and reticularis. Furthermore, angiotensin II, potassium ions and ACTH were all shown to induce ERK1 and ERK2 phosphorylation in the ZG. Treatment of adrenal capsule tissue with the specific MAPK kinase inhibitor PD98059 revealed inhibition of ERK1/2 phosphorylation, but no effect on angiotensin II-induced aldosterone secretion. Although the distribution and activation of the MAPK pathway suggest a link with proliferation, the findings clearly designated only the outer part of the glomerulosa and capsule as a potential stem cell population. Further functions should be sought for the apparently silent major part of the glomerulosa.

Journal of Endocrinology (2005) 187, 149-157

\section{Introduction}

The regulation of cell proliferation and differentiation in the adrenal cortex remains incompletely resolved. Although there are various views on the identity of the stem cell population that is thought to give rise to the zonae glomerulosa, fasciculata and reticularis, it is agreed that proliferation takes place in the outer part of the gland, and that the cells migrate centripetally, undergoing redifferentiation as they proceed (Wright 1971, Payet et al. 1980, Zajicek et al. 1986, McEwan et al. 1999). As a variant on this general theme, Mitani and co-workers have in recent years proposed that a layer of cells, the "white zone' (or zona intermedia), which lies between the zona glomerulosa and zona fasciculata and which expresses neither CYP11B1 (11ß-hydroxylase) nor CYP11B2 (aldosterone synthase), may be the origin of both the glomerulosa and fasciculata (Mitani et al. 1994, 1996, 1999).

Angiotensin II is the main regulator of zona glomerulosa function (although by no means the only one) and its actions are thought to be mediated by the angiotensin type
1 (AT1) receptor (Tanabe et al. 1998, Lumbers 1999, Mulrow 1999), which is located primarily in the zona glomerulosa (Zhuo et al. 1996). The AT1 receptor in the zona glomerulosa signals via the calcium/inositol trisphosphate second messenger pathway (Spät 1988, Catt et al. 1988, Rossig et al. 1996). However, angiotensin II is also known to stimulate the MAP kinase (MAPK) pathway which may participate in proliferation. For example, in vascular smooth muscle cells, angiotensin II is believed to be a crucial factor in regulating cell growth and migration (Duff \& Berk 1995, Touyz et al. 1999, Xi et al. 1999) while also affecting cell differentiation (Gredinger et al. 1998). There is also evidence for MAPK activation by angiotensin II in bovine adrenals (Natarajan et al. 1992, Clyne et al. 1993, Tian et al. 1999, Cherradi et al. 2003). Intracellular signalling in the zona glomerulosa has recently been reviewed (Spät \& Hunyady 2004).

In this study, cellular proliferation in the isolated outer part of the rat adrenal was investigated, together with its relationship to the distribution and activation of extracellular signal-regulated protein kinase (ERK) 1 and 2, the p44/p42 extracellular regulated kinases. 


\section{Materials and Methods}

\section{Materials}

Molecular Biology Fixative was obtained from Streck Laboratories Inc. (Omaha, NE, USA). Specific ERK1 and ERK2 antibodies were purchased from Santa Cruz (Santa Cruz, CA, USA) and their specificity was determined using Western blot (McNeill 2002). Rat serum, rabbit serum and streptavidin-biotin complex solution were purchased from DAKO (Cambridge, Cambs, UK), histomount mounting solution from National Diagnostics (Hull, Humberside, UK), sodium orthovanadate from ICN Biomedicals Inc. (Costa Mesa, CA, USA), antiphospho-p44/p42 MAPK antibody, total p44/42 MAPK antibody and the specific MAPK kinase (MEK1) inhibitor PD98059 compound were purchased from New England Biolabs (Beverly, MA, USA), while the rabbit anti-goat biotin-conjugated secondary antibody, anti-mouse horseradish peroxidase-conjugated secondary antibody, polyvinylidene difluoride (PVDF) membrane and enhanced chemiluminescence (ECL) detection system were all obtained from Amersham International plc (Amersham, Bucks, UK). Non-fat dry milk powder was purchased from a local supermarket. All other chemicals and reagents were of analytical grade and were obtained from Sigma Chemical Co. (Poole, Dorset, UK) or BDH (Dagenham, UK).

Male Wistar rats (12 weeks old) were supplied by Charles River (Margate, Kent, UK) and maintained at Queen Mary's School of Medicine and Dentistry for a minimum of 5 days. Animals were given free access to water and standard rat maintenance diet (Special Diet Services, Witham, Lincs, UK). Animals were killed between 0900 and $1100 \mathrm{~h}$ by stunning and cervical dislocation, their adrenals were removed, rapidly cleaned of adhering fat and further processed as required.

\section{Immunohistochemistry}

Following fixation, glands were embedded in paraffin wax and tissue sections $(6 \mu \mathrm{m})$ were mounted on 3aminopropyltriethyloxy-saline (Sigma)-coated slides, rehydrated by sequential washes in xylene, then reducing concentrations of ethanol, and water. Sections were incubated at $60{ }^{\circ} \mathrm{C}$ overnight in $10 \mathrm{mM}$ citrate buffer, cooled and rinsed twice in distilled water. Endogenous peroxidase activity was reduced by incubation in 3\% hydrogen peroxide for $15 \mathrm{~min}$ at room temperature. Sections were then rinsed twice in $0.01 \mathrm{M}$ phosphate-buffered saline (PBS) and non-specific reactions were blocked by incubating for $1 \mathrm{~h}$ at room temperature in $0.01 \mathrm{M}$ PBS containing $5 \%$ rat serum, $10 \%$ rabbit serum and $0.5 \%$ SDS. Anti-ERK1 or anti-ERK2 antibodies were applied at 1:100 dilution in $0.01 \mathrm{M}$ PBS containing $5 \%$ rabbit serum and $0 \cdot 2 \%$ Tween-20 for $1 \mathrm{~h}$ at room temperature, followed by three 5-min washes in 0.01 M PBS. A rabbit anti-goat biotin-conjugated secondary antibody was then added at 1:400 dilution in $0.01 \mathrm{M}$ PBS containing 4\% rabbit serum for $1 \mathrm{~h}$ at room temperature, followed by three 5-min washes in 0.01 M PBS. For ERK1, antibody binding was visualised by sequential incubation of tissue sections with streptavidin-biotin complex solution and Sigma FAST $3,3^{\prime}$-diaminobenzidine solution. Sections were washed in distilled water, dehydrated through ethanol and xylene, and mounted in histomount and viewed using a Nikon E-400 microscope.

\section{In vitro studies}

Adrenal capsules (mostly zona glomerulosa) were separated from the inner zone tissues (consisting of zona fasciculata, zona reticularis and medulla) by making an incision into the adrenal at the adrenal vein, and gently peeling back the capsule to yield intact capsule and inner zone tissue preparations.

Tissue was preincubated in tissue culture medium (Dulbecco's minimum essential medium (DMEM)) for $2 \mathrm{~h}$ at $37^{\circ} \mathrm{C}$ under an atmosphere of $95 \% \mathrm{O}_{2}$ and $5 \%$ $\mathrm{CO}_{2}$. Tissue was transferred to $1 \mathrm{ml}$ fresh DMEM and stimulants or inhibitors added as indicated and incubated at $37^{\circ} \mathrm{C}$ for different time-points, as described. Three incubations of single capsules or inner zone were used per treatment group. Following treatments, tissue was snap frozen and stored in liquid nitrogen for subsequent immunoblotting studies, or fixed and processed for immunocytochemistry. Incubation buffer was retained for steroid analysis and stored at $-20{ }^{\circ} \mathrm{C}$.

\section{5-Bromo-2'-deoxy-uridine (BrdU) staining}

Capsule and inner zone tissues were incubated separately in DMEM under $95 \% \mathrm{O}_{2} / 5 \% \mathrm{CO}_{2}$ (as described above), in the presence of specific treatments: $10^{-9} \mathrm{M}$ adrenocorticotrophin $(\mathrm{ACTH})^{1-24}, 10^{-7} \mathrm{M}$ angiotensin II or $8.4 \mathrm{mmol} / 1$ potassium. These concentrations were chosen as the maximally effective concentrations for stimulating aldosterone secretion in this preparation (data not shown). After $24 \mathrm{~h}$ or 8 days, incubation-treated media were removed and tissues were incubated with $10 \mu \mathrm{mol} \mathrm{BrdU}$ for $6 \mathrm{~h}$. BrdU detection was carried out using BrdU detection kit II (Roche Molecular Biochemicals, Lewes, E Sussex, UK).

Paraffin wax-embedded tissue sections $(6 \mu \mathrm{m})$ were prepared. Following dewaxing in xylene, sections were rehydrated through a series of decreasing alcohol concentrations and washed three times in buffer (PBS). Sections were then covered with anti-BrdU mouse monoclonal antibody (clone BMG 6H8) containing nucleases, diluted $1: 10$ with $66 \mathrm{mM}$ Tris buffer containing $0.66 \mathrm{mM} \mathrm{MgCl}_{2}$ and $1 \mathrm{mM}$ 2-mercaptoethanol. Sections were incubated for $30 \mathrm{~min}$ in a humid atmosphere at $37^{\circ} \mathrm{C}$. Following 
this, slides were washed three times in PBS and covered with a sufficient amount of purified anti-mouse Ig-alkaline phosphatase from sheep diluted 1:10 with PBS for $30 \mathrm{~min}$ in a humid atmosphere at $37^{\circ} \mathrm{C}$ and washed again three times in PBS. Detection was then carried out by the application of a colour substrate solution. Colour substrate solution was prepared by adding $13 \mu 175 \mathrm{mg} / \mathrm{ml}$ nitroblue tetrazolium salt in $75 \%$ dimethylformamide $(\mathrm{v} / \mathrm{v})$ and $10 \mu \mathrm{l}$ $50 \mathrm{mg} / \mathrm{ml}$ 5-bromo-4-chloro-3-indolyl phosphate toluidinium in dimethylformamide to $3 \mathrm{ml}$ substrate buffer containing $100 \mathrm{mM}$ Tris- $\mathrm{HCl}, 100 \mathrm{mM} \mathrm{NaCl}$ and $50 \mathrm{mM} \mathrm{MgCl} 2, \mathrm{pH} 9.5\left(20^{\circ} \mathrm{C}\right)$. Following the addition of colour substrate solution, slides were placed in the dark at room temperature for 25-30 $\mathrm{min}$, then colour substrate solution was removed by rinsing three times with PBS. Sections were mounted with an aqueous-based mountant (Kaisers glycerine gelatine) for microscopy. To quantify the staining, counts of numbers of positive staining cells were taken from three separate tissue sections counted in duplicate fields, representing a minimum of 200 cells per field.

\section{Immunoblotting analyses}

Frozen tissue was homogenised in $1.2 \mathrm{ml}$ ice-cold lysis buffer $(10 \mathrm{mM}$ Tris-HCl, $5 \mathrm{mM}$ EDTA, $50 \mathrm{mM} \mathrm{NaCl}$, $50 \mathrm{mM} \mathrm{NaF}, 1 \mathrm{mM}$ sodium orthovanadate, $30 \mathrm{mM}$ sodium pyrophosphate, $10 \mathrm{mM}$ benzamidine, $1 \%(\mathrm{v} / \mathrm{v})$ Triton X-100 and $1 \mathrm{mM}$ PMSF, with $10 \mu \mathrm{g} / \mathrm{ml}$ soybean trypsin inhibitor, aprotinin, leupeptin and pepstatin $\mathrm{A}, \mathrm{pH}$ 7.4) for two 15-s bursts using a Polytron tissue homogeniser. Homogenates were centrifuged at $10000 \boldsymbol{g}$ for 15 min at $4{ }^{\circ} \mathrm{C}$ and the supernatant was retained. Protein concentrations were determined by the Bio-Rad method. Protein aliquots $(25 \mu \mathrm{g})$ were separated by SDS-PAGE in a 9\% running gel using a Bio-Rad Miniprotean III apparatus (Bio-Rad Laboratories Ltd, Hemel Hempstead, Herts, UK). Even loading of samples on the gel was confirmed using a total $\mathrm{p} 44 / \mathrm{p} 42$ MAPK antiserum. Samples were electrophoretically transferred on to PVDF membranes and blocked in Tris-buffered saline (TBS) containing $0.05 \%(\mathrm{v} / \mathrm{v})$ Tween-20 and 5\% (w/v) low fat dried milk for $1 \mathrm{~h}$ at room temperature. Membranes were incubated for $1 \mathrm{~h}$ with the primary anti-phospho-p44/p42 MAPK diluted to 1:500 in TBS-Tween containing 5\% low fat dried milk. Following four 10-min washes in TBSTween, membranes were incubated with secondary antibody for $1 \mathrm{~h}$ at room temperature. An anti-mouse horseradish peroxidase-conjugated secondary antibody was used at 1:1000 dilution. Immunoreactive bands were detected using the ECL detection system. Bands were quantified using scanning densitometry and the Bio-Rad Molecular Analyst software.

\section{Steroid radioimmunoassay}

Aldosterone was determined by direct radioimmunoassay as previously described (Kapas et al. 1992).

\section{Statistical analysis}

Statistical analysis of data was carried out either by Student's $t$-tests, one-way ANOVA with Dunnett's multiple comparison post-hoc test or two-way ANOVA with Bonferroni post-hoc test where appropriate.

\section{Results}

\section{Effects of angiotensin II on cell division}

Rat adrenal capsular tissue incubated in the presence of angiotensin II caused an increase in BrdU staining which was most prominent in the immediate subcapsular region, with scattered staining in the rest of the zona glomerulosa (Fig. 1). The increase in staining was evident after $24 \mathrm{~h}$ and persisted at 8 days (Fig. 2), compared with controls/ unstimulated tissue (Fig. 2). Neither ACTH nor high potassium had a significant effect on cell division as measured by BrdU staining (Fig. 2).

\section{Localisation of MAPK in the rat adrenal}

Immunostaining of rat adrenal sections showed that ERK1 immunoreactivity was localised throughout the zona glomerulosa and medulla, with very low levels of staining in the fasciculata and reticularis (Fig. 3). Identical distribution was obtained with ERK2 immunostaining (data not shown).

\section{Activation of MAPK}

A study of the time-course of the effects of angiotensin II on ERK1/2 phosphorylation showed maximal effects 30-60 min after the onset of stimulation (Fig. 4). The time of $30 \mathrm{~min}$ was therefore chosen for all subsequent incubations. Both angiotensin II $\left(10^{-7} \mathrm{~mol} / \mathrm{l}\right)$ and potassium $(8.4 \mathrm{mmol} / \mathrm{l})$ induced phosphorylation of ERK1 and ERK2, while ACTH $\left(10^{-9} \mathrm{~mol} / \mathrm{l}\right)$ had less effect (Fig. 4). It is noteworthy that maximal ERK2 phosphorylation preceded ERK1 phosphorylation.

\section{Inhibition of angiotensin II-mediated ERK activity by PD098059}

The optimal concentration of the MAPK kinase/MEK1 inhibitor PD98059 required to inhibit MAPK activation was found in preliminary experiments to be $100 \mu \mathrm{M}$ (data not shown). In the experiments illustrated here, tissue was incubated with $100 \mu \mathrm{M}$ PD98059 for $30 \mathrm{~min}$ prior to angiotensin II addition. There was no significant effect of the inhibitor on aldosterone secretion (Fig. 5A), although it abolished the angiotensin II stimulation of ERK1 and ERK2 phosphorylation without affecting unstimulated phosphorylation (Fig. 5B). 
(A)

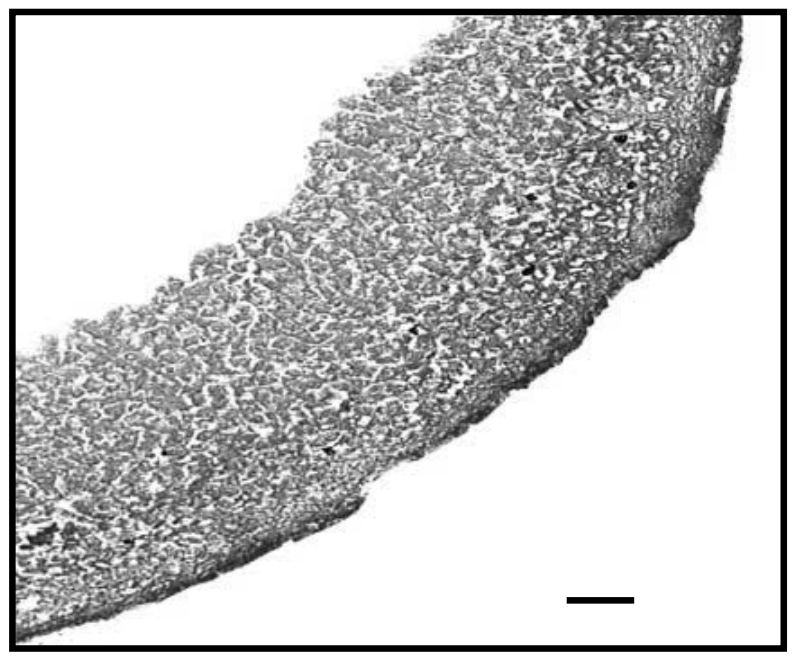

(B)

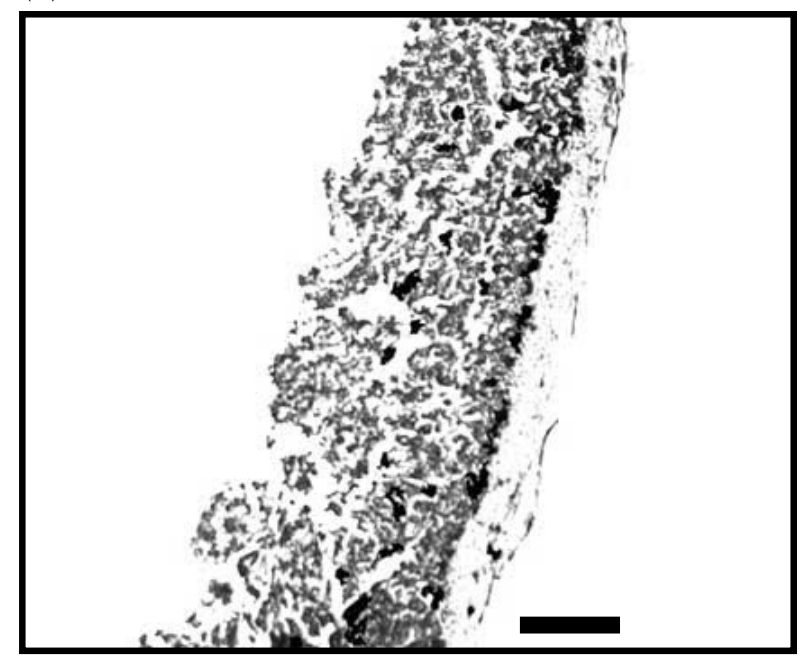

Figure 1 Effect of angiotensin II on cell division in the adrenal zona glomerulosa. BrdU-immunopositive cells are indicated by the dark staining in capsular tissue cultured in vitro for 8 days in (A) control and (B) angiotensin II treatment. Following the culture period, media were removed and capsular tissue incubated with $10 \mathrm{mmol} \mathrm{BrdU}$ for $6 \mathrm{~h}$. Tissue was then fixed, paraffin wax embedded and cut into $6 \mu \mathrm{m}$ sections. BrdU detection was carried out on capsular sections using the BrdU detection kit II. BrdU-immunopositive cells represent proliferating cell populations. Bars represent $50 \mu \mathrm{m}$.

\section{Discussion}

The specific distribution of ERK1 in the zona glomerulosa and medulla of the rat adrenal gland (Fig. 3) is of considerable interest, particularly in view of the known importance of this area of the gland as a primary site for cell proliferation and renewal in the adrenal cortex (Wright 1971, Payet et al. 1980, Zajicek et al. 1986, McEwan et al.
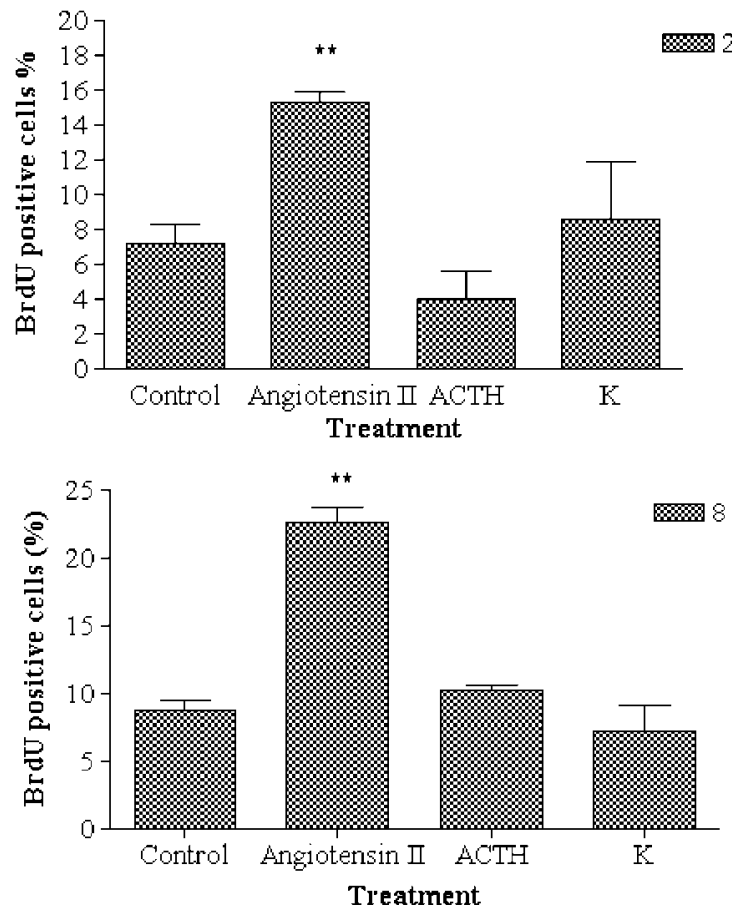

Figure 2 Percentage of proliferating zona glomerulosa cells in response to angiotensin II, ACTH and $\mathrm{K}^{+}$. Percentage of BrdU-immunopositive cells in capsular tissue cultured in vitro in the presence of $10^{-7} \mathrm{M}$ angiotensin II, $10^{-9} \mathrm{M} \mathrm{ACTH}$ and $8.4 \mathrm{mM}$ potassium (K) for (A) $24 \mathrm{~h}$ and (B) 8 days. Data represent mean percentage of BrdU-positive staining nuclei \pm S.E.M. from counts taken from three separate tissue sections counted in duplicate fields, representing a minimum of 200 cells per field compared with control. ${ }^{* *} P<0 \cdot 01$ (one-way ANOVA followed by Dunnett's post hoc test).

1999). A previous study from our laboratory, using an ERK1/2 antibody which recognises both the phosphorylated and non-phosphorylated form of the protein, reported that ERK1/2 is mainly localised in the zona glomerulosa (McNeill et al. 1998). The present data confirmed and extended these results, using specific ERK1 and ERK2 antibodies. These results are consistent with the view that although cell division in the zona fasciculata and zona reticularis cannot be excluded, the inner zones are likely to have a less important role in the generation and maintenance of the mature structure of the rat adrenal cortex. They did not suggest a special role for the white or intermediate zone in proliferation, although the manifestation of this layer of cells varies somewhat between different strains of rats, and it may be less prominent in the adrenals of Wistar rats as used in this study.

From work in other tissues it is known that MAPK activated via the AT1 receptor (Guillemot et al. 2001) has an important role in the regulation of the cell cycle, and is involved in AT1 receptor-mediated cell proliferation and 
(A)

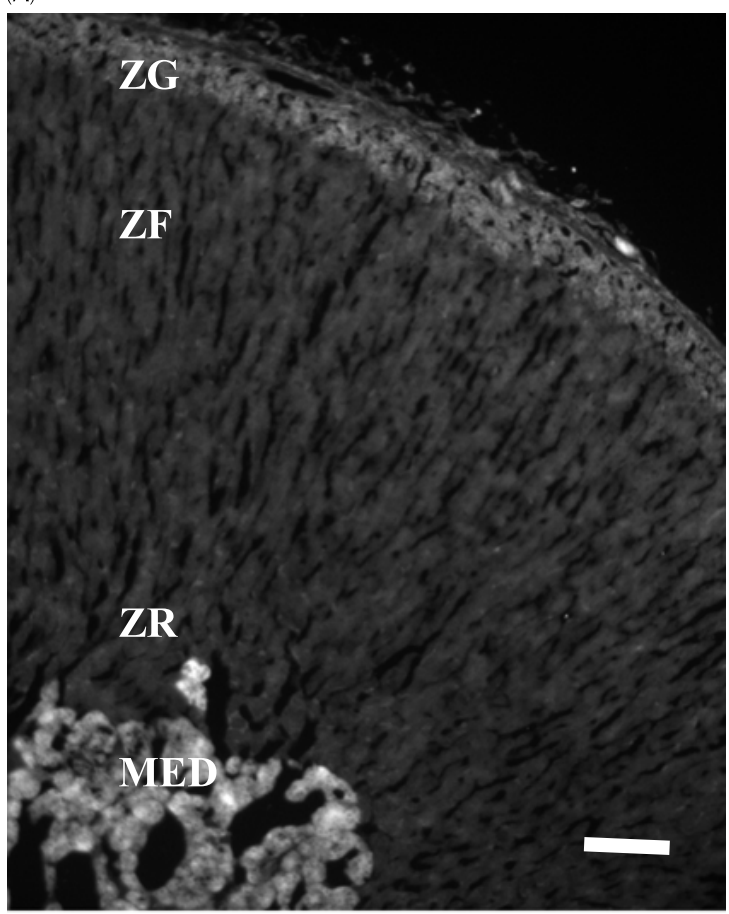

(C)

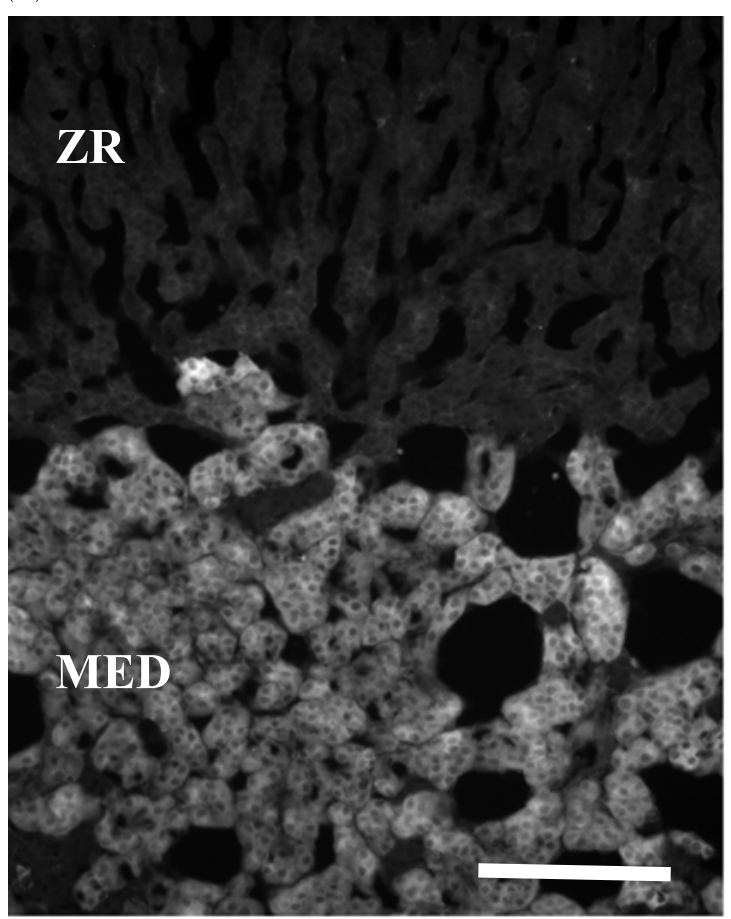

$(B)$

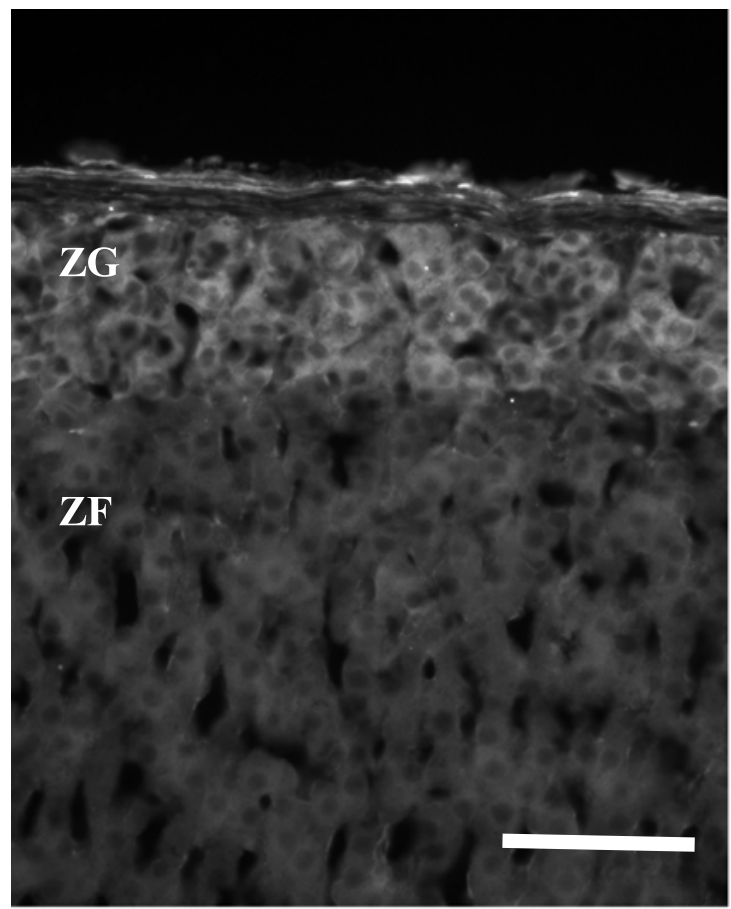

$(D)$

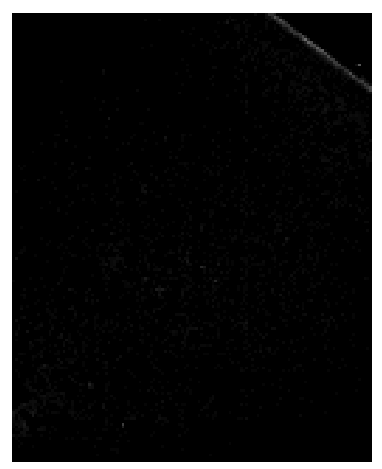

Figure 3 Localisation of ERK1 in the rat adrenal gland. (A) Sections from a rat adrenal gland showing the presence of ERK1 immunostaining in the adrenal zona glomerulosa (ZG) and medulla (MED). ZF, zona fasciculata; ZR, zona reticularis. (B) At higher magnification, immunostaining can be seen localised to a layer of four to six ZG cells and (C) with staining also prominent in the adrenal medulla. (D) Negative control in the absence of primary antibody shows no fluorescent staining apart from a thin band along the outer edge of the capsular tissue. ERK2 had an identical distribution (data not shown). Bars represent ( $A$ and D) $100 \mu \mathrm{m}$ or (B and C) $25 \mu \mathrm{m}$. 

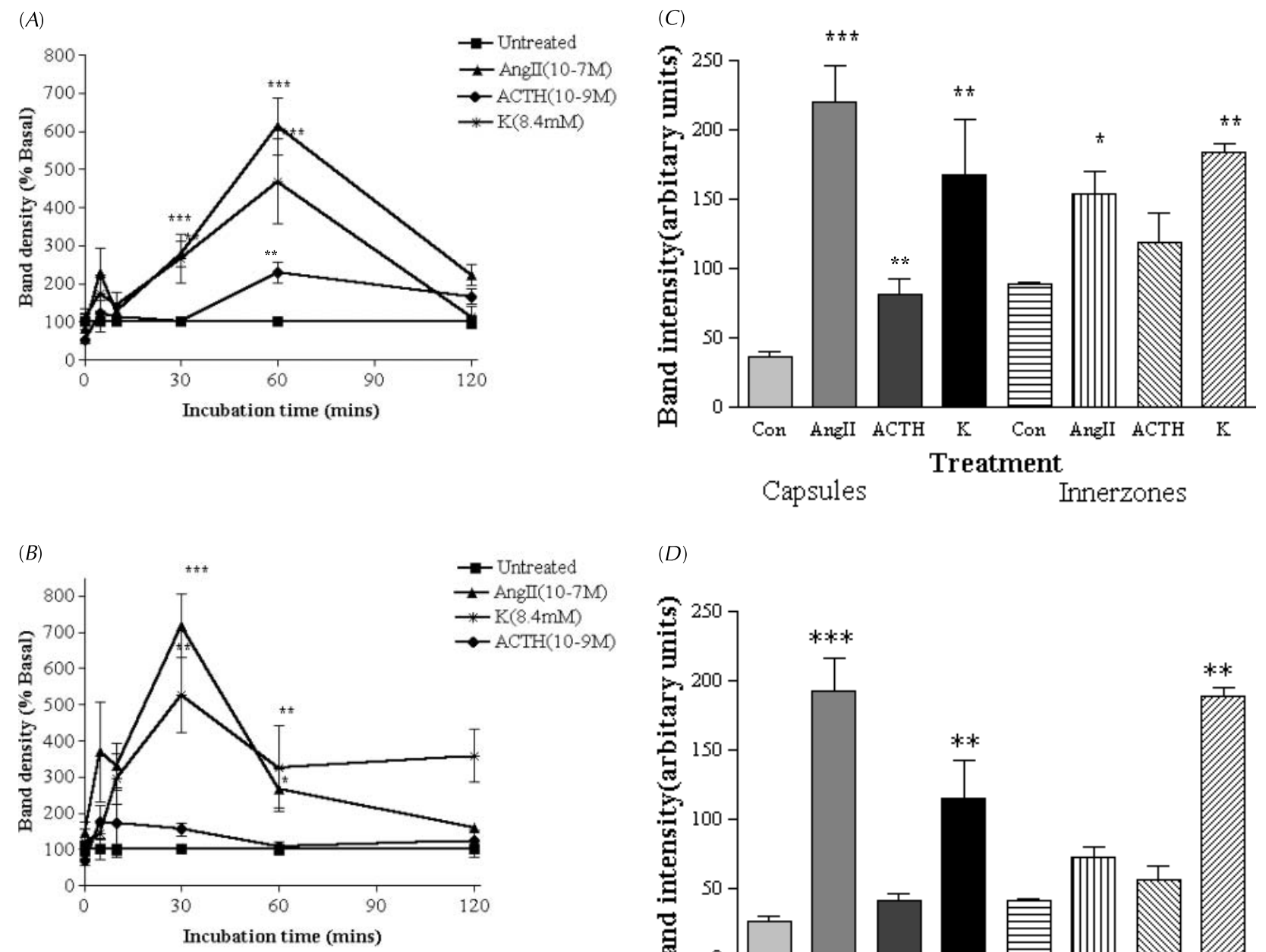

$(D)$

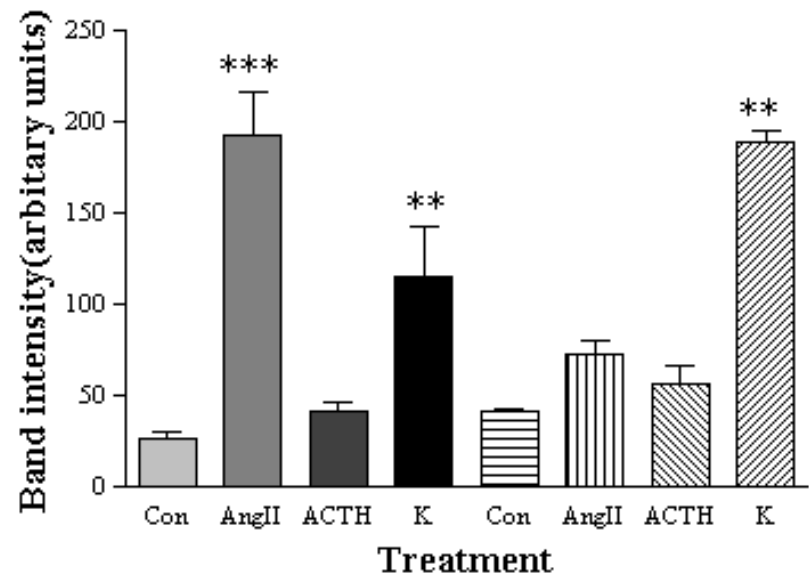

Capsules

Innerzones

Figure 4 Time-course of angiotensin II-stimulated MAPK/ERK activation in the adrenal. (A) ERK1 and (B) ERK 2 activitation in capsular tissue following treatment for $2-120 \mathrm{~min}$ with $10^{-7} \mathrm{M}$ angiotensin II (Angll), $10^{-9} \mathrm{M} \mathrm{ACTH}$ and $8.4 \mathrm{mM}$ potassium (K). Following immunoblotting and exposure to hyperfilm ECL, phospho-ERK $1 / 2$ bands were quantified by scanning densitometry using Kodak three dimensional imaging software (Hemel Hempstead, UK). ${ }^{*} P<0 \cdot 05,{ }^{* *} P<0 \cdot 01,{ }^{* *} P<0 \cdot 001$ compared with between treatments at a given time-point (two-way ANOVA with Bonferroni post hoc test). Results are presented as percentage of basal (untreated) levels where basal $=100 \% \pm$ S.E.M. from three separate Western blots. (C) Erk1 and (D) Erk2. The cumulative data for both capsules and inner zone/medullary tissue after a 60-min incubation period. Con, control.

migration in vascular smooth muscle cells (Duff \& Berk 1995, Berk \& Corson 1997, Xi et al. 1999, Touyz et al. 1999), although other pathways may also be implicated (Natarajan et al. 1992, Wen et al. 1996). The results of the present study clearly demonstrated that angiotensin II stimulates MAPK activation in the rat adrenal zona glomerulosa, and also demonstrated a stimulatory effect of high potassium, with a smaller but significant effect of ACTH. The time-course profiles of angiotensin IIstimulated MAPK activation (Fig. 4B) are in broad agreement with results obtained in other studies (e.g. Tian et al.
1999, Boulay et al. 1990), although the peak of activation was seen somewhat later in the present study, and with marked differences between rates of ERK1 and ERK2 phosphorylation.

Our results in this study also confirmed the stimulatory effect of angiotensin II on cell division in the rat adrenal gland (Marx et al. 1963, Gill et al. 1977, Nussdorfer et al. 1986, Natarajan et al. 1992). However, this is the first study which has demonstrated the proliferative actions of angiotensin II on rat adrenal tissue in vitro. In other studies, significantly using rat adrenal cell preparations, angiotensin 

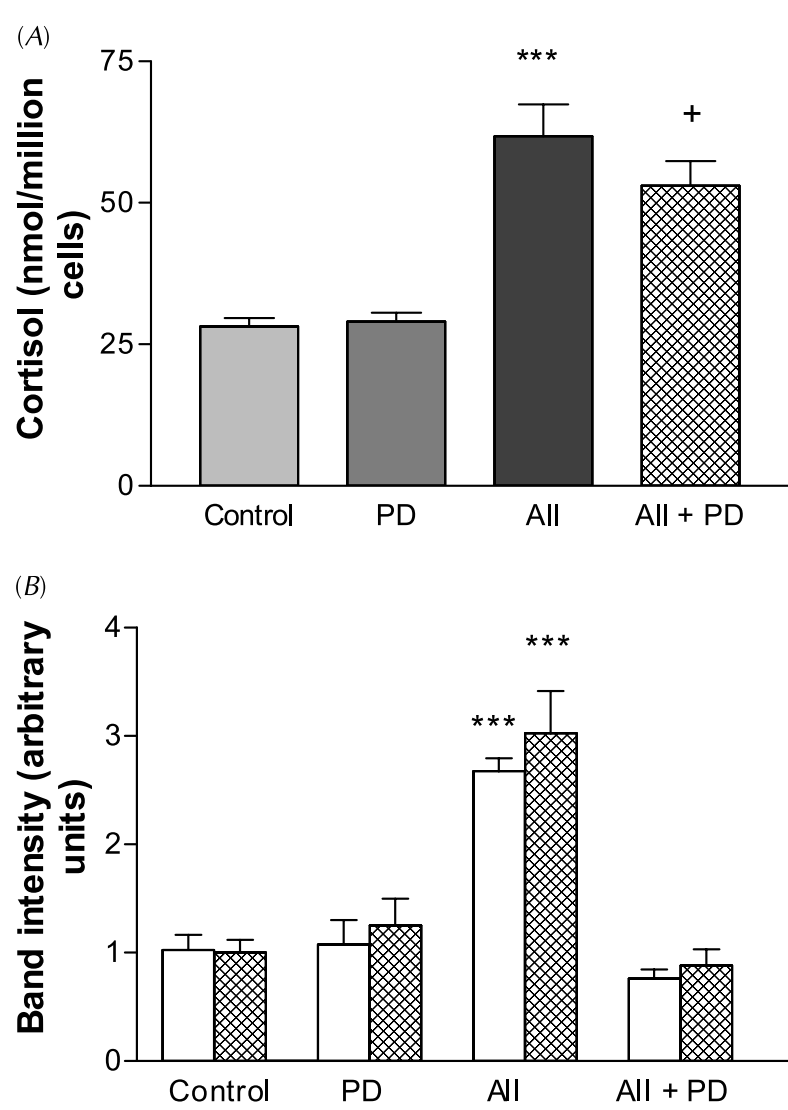

Figure 5 Effect of PD98059 on MAPK activity and aldosterone production from zona glomerulosa tissue. Adrenal zona glomerulosa tissue was stimulated with angiotensin II (AII) in the presence and absence of PD98059 (PD). PD98059 was added at a final concentration of $100 \mu \mathrm{M} 30 \mathrm{~min}$ prior to the addition of angiotensin II. (A) The effect of angiotensin II and PD98059 on aldosterone production and (B) the corresponding changes in activated ERK1 (open bars) and ERK2 (hatched bars) are illustrated. Similar results were obtained in three separate experiments. Values are means \pm S.E.M. $(n=4) .{ }^{* *} P<0 \cdot 001$ compared with control, + not significant compared with angiotensin II alone (ANOVA followed by Dunnett's post-hoc test).

II was found to inhibit proliferation (Otis et al. 2004). The critical difference between these findings may depend on the presence, in our preparation, of the connective tissue capsule, which may be of key importance in adrenal proliferation (Pignatelli et al. 2000, 2002). This concept has additional significance in the light of the present finding that the primary site of stimulated cell division lies immediately beneath the connective tissue capsule. The results contrast with data from in vivo studies (McEwan et al. 1996, 1999) in which a low sodium diet, like angiotensin II, increases BrdU staining in a wider field of the gland, although still predominantly in the glomerulosa. There are significant differences in methodology between these two studies. In McEwen et al. $(1996,1999) \mathrm{BrdU}$ was infused continuously for 2 weeks, but in our experiments, conducted in vitro, BrdU was infused only after treatment was concluded. In the prepuberal male rat, Wright et al. (1973) found that the rate of loss (presumed migration) from the glomerulosa was $0 \cdot 1$ cell/ 100 cells per $h$. Given the current understanding of centripetal migration of adrenocortical cells, it is reasonable to suppose that in the experiments of McEwan et al. (1996, 1999), centripetal migration of BrdU-labelled cells over the 2 -week period would be significant. Accordingly, it is arguable that the labelling detected in the in vivo studies could represent earlier cell division taking place in a much more limited region of the gland. The present studies suggested that this is very limited indeed. Similarly, a recent study on compensatory adrenal hypertrophy has shown that the main site of proliferation in this case was the outer fasciculate (Engeland et al. 2005). Again, this in vivo model of adrenal growth was quite different from the present in vitro system, so it is perhaps not surprising that proliferative events were located in different sites.

However, it does not appear that activation of MAPK is linked to cell proliferation in the rat adrenal. First, the distribution of ERK1/2 and that of dividing cells in the zona glomerulosa were quite different, with ERK1/2 occurring throughout the zone whereas cell division had a more limited distribution. Secondly, although angiotensin II, potassium ions and ACTH all stimulated MAPK activation, only angiotensin increased cell division. Clearly, activation of MAPK has roles other than initiation of cell division in the rat adrenal.

What, therefore, is the likely role of MAPK activation by angiotensin II in the glomerulosa? Although normally associated with proliferation, it is nevertheless a plausible concept that other glomerulosa functions could be affected by MAPK. The primary function of the zona glomerulosa is of course to synthesise and secrete aldosterone. A previous study has shown that MAPK activation is involved in the angiotensin II-stimulated activation of cholesterol ester hydrolase, and thus in the initiation of steroidogenesis (Cherradi et al. 2003). However, the use of PD98059, which prevents MAPK activation (Alessi et al. 1995), had no effect on angiotensin II-stimulated aldosterone secretion in the present study, although it inhibited angiotensin II-stimulated p42/44 ERK activation. The results suggested that if ERK1 and ERK2 are involved in aldosterone secretion, their action is minor compared with the established $\mathrm{Ca}^{2+} /$ inositol trisphosphate pathway. The role of MAPK, particularly in response to potassium and ACTH activation, remains unclear, although recent studies suggest it is involved in stimulating protein synthesis (Otis et al. 2005).

In recent publications, attention has been drawn to the relative lack of steroidogenic enzymes generally in the rat zona glomerulosa (Vinson 2003, 2004), and aldosterone synthase (like most cell division in these experiments) is confined to the outermost cell layers (Mitani et al. 1994, 
1999, Halder et al. 1998). Accordingly, it may be appropriate to consider what other functions the glomerulosa may have. Perhaps the best studied is the tissue reninangiotensin system, which is localised in the glomerulosa (Mulrow \& Franco-Saenz 1996, Vinson \& Ho 1998) but, in addition, this zone is also the source of neurotransmitters and catecholamines, more usually associated with the medulla (Ehrhart-Bornstein et al. 1998, Renshaw \& Hinson 2001).

The significance of these other functions deserves further study.

\section{Acknowledgements}

We are very grateful to the BBSRC for studentships to $\mathrm{H} \mathrm{Mc} \mathrm{N}$ and E W and for Project Grant support. This study was also supported by a grant from the Barts Cancer Committee. The authors declare that there is no conflict of interest that would prejudice the impartiality of this scientific work.

\section{References}

Alessi DR, Cuenda A, Cohen P, Dudley DT \& Saltiel AR 1995 PD 098059 is a specific inhibitor of the activation of mitogen-activated protein kinase kinase in vitro and in vivo. Journal of Biological Chemistry 270 27489-27494.

Berk BC \& Corson MA 1997 Angiotensin II signal transduction in vascular smooth muscle: role of tyrosine kinases. Circulation Research 80 607-616.

Boulay G, Gallo-Payet N \& Guillemette G 1990 Implication of phospholipase $\mathrm{C}$ in the steroidogenic action of angiotensin II. European Journal of Pharmacology 189 267-275.

Catt KJ, Balla T, Baukal AJ, Hausdorff WP \& Aguilera G 1988 Control of glomerulosa cell function by angiotensin. Clinical and Experimental Pharmacology and Physiology 15 501-515.

Cherradi N, Pardo B, Greenberg AS, Kraemer FB \& Capponi AM 2003 Angiotensin II activates cholesterol ester hydrolase in bovine adrenal glomerulosa cells through phosphorylation mediated by p42/p44 mitogen activated protein kinase. Endocrinology 144 4905-4915.

Clyne CD, Nicol MR, MacDonald S, Williams BC \& Walker SW 1993 Angiotensin II stimulates growth and steroidogenesis in zona fasciculata/reticularis cells from bovine adrenal cortex via the AT1 receptor subtype. Endocrinology 132 2206-2212.

Duff JL \& Berk BC 1995 Angiotensin II-mediated signal transduction events in vascular smooth muscle cells: kinases and phosphatases. Blood Pressure 4 (Suppl 2) 55-60.

Ehrhart-Bornstein M, Hinson JP, Bornstein SR, ScherbaumWA \& Vinson GP 1998 Intraadrenal interactions in the regulation of adrenocortical steroidogenesis. Endocrine Reviews 19 101-143.

Engeland WC, Ennen WB, Elayaperumal A, Durand DA \& Levay-Young BK 2005 Zone-specific cell proliferation during compensatory adrenal growth in rats. American Journal of Physiology: Endocrinology and Metabolism 288 E298-E306.

Gill GN, Ill CR \& Simonian MH 1977 Angiotensin stimulation of bovine adrenocortical cell growth. PNAS 74 5569-5573.

Gredinger E, Gerber AN, Tamir Y, Tapscott SJ \& Bengal E 1998 Mitogen-activated protein kinase pathway is involved in the differentiation of muscle cells. Journal of Biological Chemistry 273 10436-10444.
Guillemot L, Levy A, Zhao ZJ, Bereziat G \& Rothhut B 2001 The protein-tyrosine phosphatase SHP-2 is required during angiotensin II-mediated activation of cyclin D1 promoter in CHO-AT1A cells. Journal of Biological Chemistry 275 26349-26358.

Halder SK, Takemori H, Hatano O, Nonaka Y, Wada A \& Okamoto M 1998 Cloning of a membrane-spanning protein with epidermal growth factor-like repeat motifs from adrenal glomerulosa cells. Endocrinology 139 3316-3328.

Kapas S, Orford CD, Barker S, Vinson GP \& Hinson JP 1992 Studies on the intracellular mechanism of action of $\alpha$-melanocytestimulating hormone $(\alpha-\mathrm{MSH})$ on rat adrenal zona glomerulosa. Journal of Molecular Endocrinology 9 47-54.

Lumbers ER 1999 Angiotensin and aldosterone. Regulatory Peptides 80 91-100.

McEwan PE, Lindop GB \& Kenyon CJ 1996 Control of cell proliferation in the rat adrenal gland in vivo by the reninangiotensin system. American Journal of Physiology 271 E192-E198.

McEwan PE, Vinson GP \& Kenyon CJ 1999 Control of adrenal cell proliferation by AT1 receptors in response to angiotensin II and low-sodium diet. American Journal of Physiology 276 E303-E309.

McNeill H 2002 Angiotensin II and MAP kinase. PhD Thesis. University of London.

McNeill H, Puddefoot JR \& Vinson GP 1998 MAP kinase in the rat adrenal gland. Endocrine Research 24 373-380.

Marx AJ, Deane HW, Mowles TF \& Sheppard H 1963 Chronic administration of angiotensin II in rats: changes in blood pressure, renal and adrenal histophysiology and aldosterone production. Endocrinology 73 329-337.

Mitani F, Miyamoto H, Mukai K \& Ishimura Y 1996 Effects of long-term stimulation of ACTH-secretion and angiotensin-IIsecretion on the rat adrenal-cortex. Endocrine Research 22 421-431.

Mitani F, Suzuki H, Hata J-I, Ogishima T, Shimada H \& Ishimura Y 1994 A novel cell layer without corticosteroid-synthesizing enzymes in rat adrenal cortex: histochemical detection and possible physiological role. Endocrinology 135 431-438.

Mitani F, Mukai K, Miyamoto H, Suematsu M \& Ishimura Y 1999 Development of functional zonation in the rat adrenal cortex. Endocrinology 140 3342-3353.

Mulrow PJ 1999 Angiotensin II and aldosterone regulation. Regulatory Peptides 80 27-32.

Mulrow P \& Franco-Saenz R 1996 The adrenal renin-angiotensin system - a local hormonal regulator of aldosterone production. Journal of Hypertension 14 173-176.

Natarajan R, Gonzales N, Hornsby PJ \& Nadler J 1992 Mechanism of angiotensin II-induced proliferation in bovine adrenocortical cells. Endocrinology 131 1174-1180.

Nussdorfer GG, Kasprzak A, Mazzocchi G, Rebuffat P, Malendowicz LK \& Robba C 1986 Short- and long-term effects of angiotensin II on the rat adrenal zona glomerulosa. A coupled stereological and enzymological study. Experimental Clinical Endocrinology $\mathbf{8 8}$ $158-164$.

Otis M, Campbell S, Paget MD \& Gallo-Paget N 2005 Angiotensin II stimulates protein synthesis and inhibits proliferation in primary cultures of rat adrenal glomerulosa cells. Endocrinology 146 633-642.

Payet N, Lehoux JG \& Isler H 1980 Effect of ACTH on the proliferative and secretory activities of the adrenal glomerulosa. Acta Endocrinologica 93 365-374.

Pignatelli D, Maia M, Bento MJ, Sousa S, Azevedo ME, Magalhaes MM, Magalhaes MC \& Vinson GP 2000 Captopril effects on the rat adrenal cortex. Endocrine Research 26 965-672.

Pignatelli D, Ferreira J, Vendeira P, Magalhaes MC \& Vinson GP 2002 Proliferation of capsular stem cells induced by ACTH in the rat adrenal cortex. Endocrine Research 28 683-691.

Renshaw D \& Hinson JP 2001 Neuropeptide Y and the adrenal gland: a review. Peptides 22 429-438.

Rossig L, Zolyomi A, Catt KJ \& Balla T 1996 Regulation of angiotensin II-stimulated $\mathrm{Ca}^{2+}$ oscillations by $\mathrm{Ca}^{2+}$ influx 
mechanisms in adrenal glomerulosa cells. Journal of Biological Chemistry $27122063-22069$.

Spät A 1988 Stimulus-secretion coupling in angiotensin-stimulated adrenal cells. Journal of Steroid Biochemistry 29 443-454.

Spät A \& Hunyady L 2004 Control of aldosterone secretion: a model for convergence in cellular signalling pathways. Physiological Reviews 84 489-539.

Tanabe A, Naruse M, Arai K, Naruse K, Yoshimoto T, Seki T, Imaki T, Kobayashi M, Miyazaki H \& Demura H 1998 Angiotensin II stimulates both aldosterone secretion and DNA synthesis via type 1 but not type 2 receptors in bovine adrenocortical cells. Journal of Endocrinological Investigation 21 668-672.

Tian Y, Smith RD, Balla T \& Catt KJ 1999 Angiotensin II activates mitogen-activated protein kinase via protein kinase $\mathrm{C}$ and Ras-Raf-1 kinase in bovine adrenal glomerulosa cells. Endocrinology 139 1801-1809.

Touyz RM, Deng L-Y, He G, Wu X-H \& Schiffrin EL 1999 Angiotensin II stimulates DNA and protein synthesis in vascular smooth muscle cells from human arteries: role of extracellular signal-related kinases. Journal of Hypertension 17 907-916.

Vinson GP 2003 Adrenocortical zonation and ACTH. Microscopy Research Technique 61 227-239.

Vinson GP 2004 Glomerulosa function and aldosterone synthesis in the rat. Molecular and Cellular Endocrinology 217 59-65.

Vinson GP \& Ho MM 1998 The adrenal renin/angiotensin system in the rat. Hormone and Metabolic Research 30 355-359.
Wen Y, Nadler JL, Gonzales N, Scott S, Clauser E \& Natarajan R 1996 Mechanisms of ANGII-induced mitogenic responses: role of 12-lipoxygenase and biphasic MAP kinase. American Journal of Physiology 271 C1212-C1220.

Wright NA 1971 Cell proliferation in the prepubertal male rat adrenal cortex: an autoradiographic study. Journal of Endocrinology 49 599-609.

Wright NA, Voncina D \& Morley AR 1973 An attempt to demonstrate cell migration from the zona glomerulosa in the prepubertal male rat adrenal cortex. Journal of Endocrinology $\mathbf{5 9}$ $451-459$.

Xi XP, Graf K, Goetze S, Fleck E, Hsueh WA \& Law RE 1999 Central role of the MAPK pathway in ang II-mediated DNA synthesis and migration in rat vascular smooth muscle cells. Arteriosclerosis, Thrombosis and Vascular Biology $1973-82$.

Zajicek G, Ariel I \& Arber N 1986 The streaming adrenal cortex: direct evidence of centripetal migration of adrenocytes by estimation of cell turnover rate. Journal of Endocrinology 111 477-482.

Zhuo J, MacGregor DP \& Mendelsohn FAO 1996 In Adrenal Glands, Vascular System and Hypertension, Ch 4, pp 53-68. Eds GP Vinson \& DC Anderson. Bristol: Society for Endocrinology.

Received 13 May 2005

Accepted 26 July 2005 